\title{
Migration of Couples with Non- Employed and Employed Wives in the Netherlands: The Changing Effects of the Partners' Characteristics
}

\author{
Jeroen Smits, Clara H. Mulder and Pieter Hooimeijer
}

Data for 1977 and 1995/96 are used to study (changes in) the effects of the partners' resources on long-distance migration of couples in the Netherlands. The analyses were performed separately for couples with employed and with non-employed women. In 1977, couples with non-employed women showed the classical pattern of family migration, with strong effects of the human capital and labour market characteristics of the male and the females mostly using their power to prevent migration. The couples with employed women, on the other hand, in 1977 already showed a more modern pattern of family migration. The effects of the male's occupational prestige and sector were not significant for these couples and an age advantage of the male did not lead to more migration. Over time, the position of the employed women seems to have become even stronger and our results suggest that in 1996 at least some of them were able to initiate a move for their own career and hence to turn their husband into a tied mover.

Keywords: Long-Distance Migration; Wife's Employment; Changing Influence; Marital Power

\section{Introduction}

Long-distance migration of couples requires joint decision-making within households. The uneven power balance between men and women and traditional gender

\footnotetext{
Jeroen Smits is Senior Researcher in the Department of Economics of Nijmegen School of Management, Nijmegen University. Clara H. Mulder is Professor of Spatial Demography in the Department of Geography and Planning of the University of Amsterdam. Pieter Hooimeijer is Professor of Demography at the Institute of Urban and Regional Research, Universiteit Utrecht. Correspondence to: Jeroen Smits, Department of Economics, Nijmegen School of Management, P.O. Box 9108, 6500 HK Nijmegen, The Netherlands. E-mail: smits.jeroen@planet.nl
} 
roles have given rise to the classic pattern of family migration: in one-earner couples, the wife used to move for the career of her husband and hence became a 'tied mover'; in two-earner couples, the labour force participation of the woman might inhibit the move and the husband becomes a 'tied stayer' (Bielby and Bielby 1992; Mincer 1978; Smits 2001).

However, since these concepts were introduced, women have gained economic power and gender roles have changed. It is possible that a new pattern is emerging in which career-oriented women with good labour market prospects not only use their power to prevent family moves for the career of their partner, but also use their power to initiate such moves for their own career, and hence turn their husband into a 'tied mover'. In a recent study, we found indications that in the Netherlands in the last decades of the twentieth century, the relative influence of the female's characteristics on the migration decision has increased (Smits et al. 2003). Using large data-sets from the Dutch Labour Force Surveys, we found that between 1977 and 1996 the effect of the male partner's human capital characteristics_-age, educational level and occupational status - on family migration has become smaller. Over the same period, the influence of the female partner's labour market situation increased. While in 1977 employment of the female partner only had a negative effect on migration when the male partner was employed (and hence the need for a move was not very high), in 1996 it reduced the migration propensity in all couples.

In an earlier paper (Smits et al. 2003), the effects of the partners' characteristics on family migration were determined for all couples, one-earners and two-earners, together in one analysis. This was necessary because the focus of our analysis was on the effect of the female's employment situation. However, there are important reasons for performing separate analyses for one-earner and two-earner couples. Besides the quantitative difference between one-earner and two-earner couples in frequency of migration, there may exist qualitative differences between them. Until as late as the 1980s, gender roles were very traditional in the Netherlands. The classical pattern with the husband as breadwinner and the wife at home was very prevalent. Because the husbands earned a relatively high 'breadwinner salary' and the prices of houses were low, there was not much financial necessity for married women to work for pay (e.g. De Graaf and Vermeulen 1997; Hooghiemstra and Niphuis-Nell 1993; Van der Lippe 1997). The rather small group of married women who, against social pressure, chose to be gainfully employed at that time may have been a special group, with a different attitude towards career migration than their non-employed counterparts. And their husbands may also have differed from the average Dutch male at that time. Because of these differences, our earlier analyses may not have revealed the complete picture. Important differences between both groups of couples may have cancelled each other out, or changes over time may have been the result of compositional changes (i.e. the strong increase in the proportion of two-earner couples) and not so much of changes in the strength of the effects.

To gain more insight into these issues, the current paper studies the effects of the partners' characteristics on long-distance migration of couples separately for couples with employed and with non-employed wives. The aim of the study is to determine the 
(changes in the) effects of demographic and labour market characteristics of the partners on the couple's migration propensity over the period 1977-96. We use data from the Dutch Labour Force Surveys and we test hypotheses derived from human capital theory, marital power theory and gender role theory.

We not only focus on the direct effects of the partners' characteristics on their migration propensity but we also study an indirect one: the effect of an age difference between the partners. The dominance of the male partner in family migration may, to a certain extent, be due to the fact that in most couples he is older than the female. As a result of this age advantage, the male generally will be somewhat further in his career at any point in time, and hence may contribute more to family income, be more experienced and/or have greater authority than the female, even if the educational level of the partners is the same (Markham and Pleck 1986; Smits et al. 2003). The earlier results made clear that in 1977 only an age advantage of the male led to more migration, whereas in 1996 an age advantage of either partner increased migration. In the current paper we investigate whether these effects are present among one-earner couples, two-earner couples, or both.

\section{Theoretical Background}

Why Migrate?

Long-distance migration is generally considered to be an investment in human capital intended to generate returns in the form of increased income, employment prospects, and/or occupational status (Blau and Duncan 1967; Greenwood 1975; Sjaastad 1962). And, indeed, there is good reason to believe that geographic mobility aids career advancement. Migrants may have more favourable career developments than (otherwise comparable) non-migrants because migration allows individuals to compete for more jobs. They may take advantage of opportunities elsewhere that cannot be used by people who are unable to move; by changing jobs more often, migrants may accumulate experience more rapidly (Blau and Duncan 1967; Lichter 1983; Markham and Pleck 1986; Mincer 1978).

Job mobility is the dominant trigger for long-distance migration of individuals and families. The literature on human capital and job mobility shows that this mobility is highest at younger ages (Topel and Ward 1992), due to the fact that wage gains decrease with age, as does the remaining number of working years to recoup the costs of a job change (Mincer 1978; Simpson 1992). Higher-educated workers show a higher level of job mobility because they tend to have faster careers and need job changes to step up on the career ladder (Bartel and Lichtenberg 1987; Van Ham et al. 2001).

The mobility preference is lower among women than among men (Bielby and Bielby 1992; Markham 1987). This is generally explained by their lower wage rate, generating a division of labour in which women concentrate on domestic and child care rather than gainful employment (Becker 1981). Alternatively, it may be explained by traditional values that lead to a low priority in pursuing a career (Hanson and Pratt 1990). 
Job mobility only leads to migration when suitable job opportunities are lacking within a reasonable commuting distance. The market for higher-paid specialist positions is geographically less dense than the market for lower-paid work (e.g. Mulder 1993; Shaw 1975; Simpson 1992). Thus, not only do the more highly educated show a higher level of job mobility, but they also have to migrate more for their jobs. Because of the uneven geographical distribution between industries, migrating for a job change may vary across sectors of the economy. The unemployed may show higher migration rates because they may need to expand their job search area if they cannot find a job near their homes.

\section{The Costs of Migration}

Though migration yields gains, these come at a price. And like the gains, the price varies among individuals or couples with different characteristics. Older persons, for instance, tend to migrate less because their gains are lower, but also because the financial and psychological costs of moving are higher for them than for younger persons (Markham 1987). Older couples have generally already settled down, have invested in their local social network, and tend to own their homes-all of which makes it less attractive to relocate (Mulder 1993).

The costs of migration are higher when the individual who wants to move is living with a partner or when there are children in the household. In most cases, the advantages of a career-motivated move accrue mainly to the person on whose behalf the move is undertaken. For the partner (and other family members), the move is often less favourable. This is especially true for partners who have invested deeply in a local social network or who want to have a career of their own and who have a promising job.

Because of the traditional division of labour that existed in many householdswith the husband in the provider role and the wife responsible for the home and children-most long-distance moves of families used to take place for the sake of the husband's career (Bielby and Bielby 1992; Bonney and Love 1991; Markham and Pleck 1986). Several explanations have been offered for the fact that many married women used to accept such a move despite considerable personal losses. First, proponents of the human capital theory point to the fact that married women generally contribute less to family income than their husbands. As a result, the personal losses of the wife may be counterbalanced by the gain from the move for the family as a whole (Mincer 1978; Polachek and Horvath 1977). Second, according to the resource theory of conjugal power (Blood and Wolfe 1960; Rodman 1972), the balance of power within most conjugal units lies with the husband because he brings more valued resources to the marriage. This implies that the husband exerts most influence on the migration decision. Third, gender-role theorists argue that women often defer to their spouse on economic decisions because they are socialised to place family first and personal goals second when it comes to critical household matters (Markham and Pleck 1986; Shihadeh 1991).

The fact that most long-distance moves of married women used to be for their husband's career does not mean that married women had no say at all in the migration 
decision. However, because they were often inconvenienced by a move-e.g., losing their jobs and their social networks-these women mainly used their influence to prevent migration (Long 1974; Mincer 1978; Shaklee 1989; Spitze 1984). For this reason, 'tied stayers' used to be most often married men (Mincer 1978). With the increase of female labour-force participation, however, the proportion of female 'tied stayers' has probably grown.

Unfortunately, it is hard to say how much influence each of the partners has on the migration decision. The reason is that it is difficult to distinguish couples on the grounds of their motivation. Those who do not move because neither one of the partners want to are indistinguishable from couples who do not move because one of the partners refuses to do so. However, there may be indirect evidence of this influence. For example, we can study how specific characteristics of the partners affect the couple's propensity to migrate. That is the strategy we follow in this paper.

\section{Differences Between the Partners}

In the previous section, arguments from human-capital, family-power and gender-role theory were used to explain the prevalence of husband-centred migration. Parts of those arguments are formulated in terms of relative levels of resources and power. It is therefore important to study the effects of the female partner's resources in comparison with those of the male partner (Boyle et al. 1999; Lichter 1983; Shihadeh 1991). The underlying assumption is that a difference in resources makes it easier for the more well-endowed partner to push through a move for his or her own career. An unequal balance in earning capacity can be expected to contribute to the couple's migration propensity, regardless of which partner has this capacity. The balance of gains and losses favours a move for the sake of the partner with the highest earning capacity, who also has more power to push through a move. So the greater the difference in resources, the more likely that the couple will move, all else being equal. In our previous paper, this prediction was called the power-balance hypothesis (Smits et al. 2003).

The effect of the age difference between the partners is especially interesting. In most couples, the female partner is younger than the male. In the Netherlands, this age difference at first marriage was two to three years in the period under study (Smeenk 1998), Thus, even if their educational level was the same, the male partner on average would have been somewhat further on in his career and hence earn more or have a higher occupational prestige than the female partner (Markham and Pleck 1986; Shihadeh 1991). So, on the basis of both human-capital and family-power arguments, the male's characteristics can be expected to count more. In addition to this, the male partner might also have derived a psychological advantage of being older than his partner. An authority difference derived from the age difference of two to three years might have strengthened his influence on major household decisions independent of the effects of his more 'objective' human capital characteristics.

However, these arguments do not hold for the small number of couples in which the wife is older than the husband. If it is the difference in resources that counts, the migration decision would be facilitated by an age advantage, regardless of which partner is 
older. On the other hand, if the male is dominant in the migration decision (as in the classic Mincerian and gender-role viewpoints), migration would only be facilitated by a higher age of the male. In that situation, the female partner has few possibilities to initiate a move for her own career. Therefore, we would expect her to use the influence derived from her age advantage to prevent migration.

The effects of the human-capital, power-balance and gender factors may work out differently for couples in different circumstances. An important condition in this respect is the presence of children in the household. Couples without children can migrate more easily because they face fewer restrictions. If there are children, more persons are involved in the migration decision. For older children it may be a problem to change to another school. Moreover, they probably do not want to give up their social network and start all over in another place. If there are young children, the number of restrictions on the female partner is high. Even in the most modern societies, females still bear most responsibility for the children (Gregson and Low 1993; Van der Lippe 1997).

\section{Employment of the Female Partner}

Whether the female partner in a couple works is in itself an indicator of her human capital and marital power. In our previous paper, we found that female employment leads to less migration — at least, if the male partner is also employed (Smits et al. 2003). Given employment or non-employment of the female partner, we have reason to expect different effects of other factors on the likelihood of migration.

In the 'traditional' as well as the 'modern' situation, women with a paid job are, on average, more work- and career-oriented than women without a paid job. We therefore expect the employed women to use their power and resources as much as possible in the interest of their own work and career. In the traditional situation, where migration for the female's career was very unlikely, we expect employed women with a high educational level to use the power derived from this human capital to prevent migration. Higher-educated women without a job are probably less inclined to prevent migration, because they have less to lose. Compared to women with less education, they may even more easily accept migration. That is because many of them have already experienced a long-distance move before, namely to the place where they were enrolled in higher education. Making a second long-distance move is probably easier for them than for persons who have never left the place where they grew up. Because of the work and career orientation of employed women and their greater power within the relationship, we also expect the effects of the male's human capital to be weaker when the female partner is employed.

The effect of the presence of children in the household may also work out differently for women with a paid job than for non-employed women. The negative effect of employment of the female partner on migration will be stronger in households with children, because mothers need to arrange child care and/or find a job with flexible working hours. When they are employed, they have already managed to make those arrangements and will probably be very hesitant to give up the status quo. The negative 
effect of the presence of children on migration, therefore, is expected to be stronger in two-earner couples than in couples where only the male is employed.

\section{Changes Over Time}

The period 1977-96 was a very dynamic time in the Netherlands. It was characterised by a very strong increase of the labour-force participation and a growing career orientation among married women. As a result of several related developments - the declining number of children in the family, the increasing educational level of women, a shift in the employment structure to sectors with more jobs for women, the higher unemployment rates that increased the financial need for women to work for pay, and women's emancipation-more and more women remained employed or reentered the workforce after getting married and after the birth of their children (see, for example, De Graaf and Vermeulen 1997; Green 1995; Hooghiemstra and NiphuisNell 1993). In the wake of this development, there was a strong decrease in the number of families who lived according to the traditional marriage and family pattern, in which the man was the breadwinner and the woman was the housewife. Because over the same period the importance that married women attached to their jobs also increased, not only the number of two-earner couples but also the number of two-career couples increased considerably (Bonney 1988; Green 1995; McRae and Daniel 1991).

Given the increase in economic power of married women and their stronger work and career orientation in 1996 compared to 1977, the relative influence of characteristics of the female on the migration decision compared to the influence of characteristics of the male was expected to have increased in this period. The findings in our earlier study indeed confirmed this to have been the case in the Netherlands. However, because that study did not differentiate between employed and non-employed women, we still do not know whether the developments were the same for both categories of women. Most of the arguments given so far are about employed wives and it is less obvious why the influence on the migration decision of non-employed wives should have changed in the same way.

However, there are reasons to expect things to have changed for the nonemployed women as well. Part of the changes that took place in Dutch society-like the decreasing number of children, the increasing educational level of women, and women's emancipation-can be expected to have strengthened the position of all women, independent of their employment status. It also seems likely that, because of the developments taking place in society at large, the choice of a married woman to stay at home to take care of the household and children has become less self-evident. More than before, in the modern 'bargaining household', a woman's decision to make this choice might be seen as a sacrifice which she makes for her family and for which she has to be compensated in other ways, for example by letting her wish weigh heavier in other important household decisions. It seems likely, therefore, that the relative influence of non-employed women on the migration decision has also increased over time. 


\section{Data, Method and Measurement}

Data

The data used in this paper were derived from the Dutch Labour Force Surveys (LFS), which were conducted in 1977, 1995, and 1996 by Statistics Netherlands. The data-sets of the 1995 and 1996 LFS were pooled, because the number of respondents in the recent 1995 and 1996 LFS is lower than in the 1977 LFS and because the number of longdistance moves is rather small in the Netherlands (Smits 1999). Because the 1977 and $1995 / 96$ files had to be analysed at different locations, it was necessary to perform separate analyses for both time periods. For reasons of simplicity, we will speak of (data for) 1996 when referring to the combined 1995/96 data-set. The number of cases used in the analyses is 49,036 for 1977 and 37,568 for 1995/96.

The analyses in this paper are restricted to married and cohabiting persons, aged 22-59. The lower age limit is set at 22 to rule out migration for reasons of education as much as possible. The upper limit is age 60, because in 1996 many persons of that age had already left the labour market due to retirement or disability. The analyses are restricted to those respondents who formed a couple before the potential move. Those who made a move to start living with their partner are left out of the analysis to avoid confounding effects of migration for reasons of household formation.

\section{Method}

To assess the effect of characteristics of the male and female partner on long-distance migration, we used logistic regression analysis. The dependent variable in these analyses is a dummy variable which takes the value of ' 1 ' for couples who migrated over a long distance in the year before the survey and a value of ' 0 ' for couples who did not move or only moved over a short distance. The distinction between long-distance migration and other forms of migration is based on the division of the Netherlands in 12 provinces. All moves in which at least one province boundary was crossed are considered to be long-distance moves. This operationalisation on the basis of geographic units instead of in kilometres or miles was necessary because for 1977 no other information about the distance of migration is available. For each year, two logistic regression models are estimated, one model for the couples with non-employed females and one model for the couples with employed females.

\section{Independent Variables}

The characteristics of the partners that are used to explain the migration behaviour of the couple include their age and educational level and several characteristics of their work situation. To indicate the household situation, information on the presence and age of children is used.

Because of the high correlation between the ages of married persons, the couple's 'age' is indicated by the age of the husband. This age variable is measured in years. The educational levels of the partners are divided into four categories: (1) primary 
education, (2) lower-level secondary education, (3) upper-level secondary education, and (4) tertiary education. These variables are entered in the form of three dummies, with the category 'primary education' as reference category. The presence of children in the household is classified according to the following three categories: (1) no children, (2) also children under age 6, and (3) only children aged 6 and older.

The industrial sectors of the male and female partner one year before the interview were indicated by four categories: (1) manufacturing and construction, (2) agriculture, (3) commercial services, and (4) non-profit sector. Dummies were used for these variables with 'manufacturing and construction' as reference category. The distance over which the partners had to commute to their work one year before the interview was measured with dummy variables indicating whether (1) or not (0) the place of work was in the same province as the place of residence. We also included dummy variables to indicate employed individuals with missing values for the industrial sector and the commuting distance variables. Unemployment of the male was measured with a dummy variable indicating whether $(1)$ or not (0) one year before the interview he was unemployed.

The occupational prestige of the partners was measured with the occupational prestige scale for the Netherlands (Sixma and Ultee 1983). This variable was only available for the moment of the interview and hence only applies to males and females who were employed at that time. We substituted missing values on occupational prestige with the average prestige of the persons of the same sex and included dummy variables to indicate the couples for whom the prestige scores were substituted. For individuals without a job one year before the interview, the averages of the values for individuals of the same sex with a job were substituted in the dummies for occupational sector, commuting distance, and occupational prestige. For reasons of clarity, the coefficients of the missing value dummies are not presented in the tables with the results.

As in our preceding study (Smits et al. 2003) we use two variables to estimate the effects of age difference between the spouses: the age difference in years (the male's age minus the female's age) and the absolute value of the age difference in years. The variable for the absolute age difference indicates the difference regardless of which partner is older; it is denoted as the symmetrical age difference variable. The variable for the age difference as such (which will be called the asymmetrical age difference variable) indicates how many years older the male is, pointing to a greater importance of the male. We test the contribution to the model of each variable separately and choose the variable with the greatest contribution.

\section{Results: The Number of Long-Distance Moves}

Table 1 gives an overview of the migration behaviour of couples with employed and with non-employed females in the Netherlands in 1977 and 1996. The figures show that couples with employed females tended to move more than couples in which the female did not work for pay. In 1977, 2.5 per cent of the couples with employed females moved 
Table 1. Migration in the year before the interview among couples with non-employed females and couples with employed females in the Netherlands

\begin{tabular}{|c|c|c|c|c|}
\hline \multirow[b]{2}{*}{ Migrated } & \multicolumn{2}{|c|}{ Female not employed } & \multicolumn{2}{|c|}{ Female employed } \\
\hline & 1977 & $1995 / 96$ & 1977 & $1995 / 96$ \\
\hline Not/within community & $47,859(97.6)$ & $36,832(98.0)$ & $13,174(95.9)$ & $29,859(97.0)$ \\
\hline $\begin{array}{l}\text { To another municipality within } \\
\text { province }\end{array}$ & $673(1.4)$ & $391(1.0)$ & $346(2.5)$ & $606(2.0)$ \\
\hline To another province & $504(1.1)$ & $345(0.9)$ & $219(1.6)$ & $327(1.0)$ \\
\hline Total & $49,036(100)$ & $37,568(100)$ & $13,739(100)$ & $30,792(100)$ \\
\hline
\end{tabular}

to another community within the same province and 1.6 per cent of them moved to another province. For couples with non-employed females, these percentages were 1.4 per cent and 1.1 per cent respectively. The fact that, in 1977, couples with employed females migrated more than couples with non-employed females may be surprising. However, this probably is due to the fact that couples in which the female is employed were over-represented among the young, the highly educated, and the childless couples (Smits et al. 2003).

Between 1977 and 1996, the incidence of both forms of migration decreased for both kinds of couple, but the incidence of interprovincial migration decreased more among the couples with employed females. As a result, in 1996, the difference in interprovincial migration between both kinds of couple has almost disappeared. In that period, about 1 per cent of both kinds of couple moved interprovincially.

\section{Logistic Regression Results}

Tables 2 and Tables 3 present the results of the logistic regression analyses which explain the odds of a couple making an interprovincial move on the basis of characteristics of both partners and their households. In our earlier study we found that in 1977 the male's human capital and employment characteristics were more important than those of the female. A higher educational level or occupational prestige, unemployment, or a long commuting distance of the husband led to more migration, and a higher age or working in manufacturing to less (Smits et al. 2003). Of the female partner's characteristics, only educational level and a long commuting distance had a (positive) effect on migration, and these effects were less pronounced than those of the husband. Together these results strongly suggested the presence of male dominance in 1977. The age difference effect in that year also pointed in this direction: the asymmetrical age difference variable was significantly positive, which means that a higher age advantage of the male partner led to more migration and a higher age advantage of the female partner to less. This indicates that the males used the advantage derived from a higher age to push through a move for their career (if necessary), whereas the females mostly used such an advantage to prevent migration. 


\section{Couples with Non-Employed Females}

Table 2 presents the models for the couples with non-employed females. These turn out to be almost the same as the results for all couples in the earlier study. For 1977 we find that also among the couples with non-employed females, a higher educational level or occupational prestige, working outside the province and unemployment of the

Table 2. Logistic regression coefficients (B) for the effects of selected characteristics of husbands and wives on interprovincial migration of couples with a non-employed female partner in the Netherlands, and differences between the coefficients

\begin{tabular}{|c|c|c|c|c|c|}
\hline & \multicolumn{2}{|c|}{1977} & \multicolumn{2}{|c|}{$1995 / 96$} & \multirow{2}{*}{$\frac{1995 / 96-77}{\text { Difference }^{b}}$} \\
\hline & B & $\mathrm{SE}(\mathrm{B})$ & B & $\mathrm{SE}(\mathrm{B})$ & \\
\hline Constant & $-4.944^{\star \star}$ & 0.344 & $-3.395^{\star \star}$ & 0.414 & $1.549^{* *}$ \\
\hline Age husband & $-0.048^{\star *}$ & 0.007 & $-0.069^{\star *}$ & 0.007 & $-0.021^{\star}$ \\
\hline \multicolumn{6}{|l|}{ Education husband: } \\
\hline Primary & \multicolumn{2}{|c|}{ Reference category } & \multicolumn{2}{|c|}{ Reference category } & \\
\hline Lower secondary & $0.415^{\star *}$ & 0.157 & -0.240 & 0.234 & $-0.655^{\star}$ \\
\hline Upper secondary & $0.692^{\star *}$ & 0.166 & 0.115 & 0.213 & $-0.577^{\star}$ \\
\hline Tertiary & $0.765^{\star \star}$ & 0.194 & $0.494^{\star}$ & 0.238 & -0.271 \\
\hline \multicolumn{6}{|l|}{ Education wife: } \\
\hline Primary & \multicolumn{2}{|c|}{ Reference category } & \multicolumn{2}{|c|}{ Reference category } & \\
\hline Lower secondary & 0.094 & 0.123 & 0.254 & 0.229 & 0.160 \\
\hline Upper secondary & $0.481^{\star *}$ & 0.148 & $0.737^{\star *}$ & 0.220 & 0.256 \\
\hline Tertiary & $0.721^{\star *}$ & 0.190 & $0.889^{* *}$ & 0.249 & 0.168 \\
\hline Male unemployed & $1.463^{\star \star}$ & 0.159 & $0.880^{* \star}$ & 0.140 & $-0.583^{\star *}$ \\
\hline Occupational prestige husband ${ }^{\mathrm{a}}$ & $0.016^{\star *}$ & 0.003 & 0.001 & 0.005 & $-0.015^{\star}$ \\
\hline \multicolumn{6}{|l|}{ Industrial sector husband ${ }^{\mathrm{a}}$ : } \\
\hline Manufacturing/construction & \multicolumn{2}{|c|}{ Reference category } & \multicolumn{2}{|c|}{ Reference category } & \\
\hline Agriculture & 0.237 & 0.321 & 0.148 & 0.436 & -0.089 \\
\hline Commercial services & $0.639^{* *}$ & 0.123 & $0.350^{*}$ & 0.166 & -0.289 \\
\hline Non-profit sector & $0.642^{\star \star}$ & 0.138 & $0.481^{\star}$ & 0.188 & -0.161 \\
\hline Workplace husband outside province ${ }^{\mathrm{a}}$ & $2.381^{\star *}$ & 0.108 & $1.933^{\star *}$ & 0.148 & $-0.448^{\star}$ \\
\hline \multicolumn{6}{|l|}{ Children: } \\
\hline None & \multicolumn{2}{|c|}{ Reference category } & \multicolumn{2}{|c|}{ Reference category } & \\
\hline Youngest $<6$ & -0.034 & 0.145 & $-0.430^{\star *}$ & 0.131 & $-0.396^{*}$ \\
\hline Youngest $>=6$ & $-0.611^{\star *}$ & 0.156 & $-0.679^{\star *}$ & 0.164 & -0.068 \\
\hline $\mathrm{N}$ & \multicolumn{2}{|c|}{49,036} & \multicolumn{2}{|c|}{37,568} & \\
\hline $\mathrm{N}$ migrated & \multicolumn{2}{|c|}{504} & \multicolumn{2}{|c|}{345} & \\
\hline-2 Log Likelihood & \multicolumn{2}{|c|}{4,661} & \multicolumn{2}{|c|}{3,389} & \\
\hline Model Chi-Square/DF & \multicolumn{2}{|c|}{$956 / 18$} & \multicolumn{2}{|c|}{$534 / 18$} & \\
\hline
\end{tabular}

Notes: ${ }^{a}$ The dummy variables for cases with missing values on these variables are not presented. ${ }^{\mathrm{b}}$ Significance of the differences between the years is tested with T-tests for independent samples. ${ }^{*} \mathrm{p} \leq 0.05{ }^{\star *} \mathrm{p} \leq 0.01$. 
294 J. Smits, C. H. Mulder and P. Hooimeijer

Table 3. Logistic regression coefficients (B) for the effects of selected characteristics of husbands and wives on interprovincial migration of couples with an employed female in the Netherlands, and differences between the coefficients

\begin{tabular}{|c|c|c|c|c|c|}
\hline & \multicolumn{2}{|c|}{1977} & \multicolumn{2}{|c|}{$1995 / 96$} & \multirow{2}{*}{$\frac{1995 / 96-77}{\text { Difference }^{b}}$} \\
\hline & B & $\mathrm{SE}(\mathrm{B})$ & B & $\mathrm{SE}(\mathrm{B})$ & \\
\hline Constant & $-5.799^{\star *}$ & 0.588 & $-3.403^{* *}$ & 0.573 & $2.396^{\star *}$ \\
\hline Age husband & $-0.044^{\star *}$ & 0.011 & $-0.082^{\star *}$ & 0.009 & $-0.038^{\star *}$ \\
\hline \multicolumn{6}{|l|}{ Education husband: } \\
\hline Primary & \multicolumn{2}{|c|}{ Reference category } & \multicolumn{2}{|c|}{ Reference category } & \\
\hline Lower secondary & $0.694^{*}$ & 0.305 & -0.254 & 0.352 & $-0.948^{\star}$ \\
\hline Upper secondary & $1.096^{* *}$ & 0.306 & 0.010 & 0.324 & $-1.086^{*}$ \\
\hline Tertiary & $1.275^{\star *}$ & 0.334 & 0.536 & 0.343 & -0.739 \\
\hline \multicolumn{6}{|l|}{ Education wife: } \\
\hline Primary & \multicolumn{2}{|c|}{ Reference category } & \multicolumn{2}{|c|}{ Reference category } & \\
\hline Lower secondary & -0.017 & 0.236 & -0.406 & 0.360 & -0.389 \\
\hline Upper secondary & 0.241 & 0.262 & -0.096 & 0.338 & -0.337 \\
\hline Tertiary & -0.143 & 0.330 & 0.134 & 0.361 & 0.277 \\
\hline Male unemployed & $1.739^{* *}$ & 0.202 & $0.506^{* *}$ & 0.192 & $-1.233^{\star *}$ \\
\hline Occupational prestige husband ${ }^{\mathrm{a}}$ & 0.008 & 0.006 & 0.007 & 0.005 & -0.001 \\
\hline Occupational prestige wife $\mathrm{e}^{\mathrm{a}}$ & $0.016^{*}$ & 0.007 & 0.001 & 0.005 & -0.015 \\
\hline \multicolumn{6}{|l|}{ Industrial sector husband ${ }^{\mathrm{a}}$ : } \\
\hline Manufacturing/construction & \multicolumn{2}{|c|}{ Reference category } & \multicolumn{2}{|c|}{ Reference category } & \\
\hline Agriculture & 0.266 & 0.665 & 0.335 & 0.431 & 0.069 \\
\hline Commercial services & 0.370 & 0.209 & $0.326^{*}$ & 0.166 & -0.044 \\
\hline Non-profit sector & 0.256 & 0.224 & 0.193 & 0.188 & -0.063 \\
\hline \multicolumn{6}{|l|}{ Industrial sector wife ${ }^{\mathrm{a}}$ : } \\
\hline Manufacturing/construction & \multicolumn{2}{|c|}{ Reference category } & \multicolumn{2}{|c|}{ Reference category } & \\
\hline Agriculture & -0.543 & 1.084 & 0.634 & 0.488 & 1.177 \\
\hline Commercial services & 0.141 & 0.240 & 0.173 & 0.216 & 0.032 \\
\hline Non-profit sector & -0.005 & 0.243 & 0.162 & 0.217 & 0.167 \\
\hline Workplace husband outside province ${ }^{\mathrm{a}}$ & $1.896^{* *}$ & 0.184 & $1.994^{* *}$ & 0.139 & 0.098 \\
\hline Workplace wife outside province ${ }^{a}$ & $1.362^{* *}$ & 0.237 & $1.046^{* *}$ & 0.133 & -0.316 \\
\hline \multicolumn{6}{|l|}{ Children: } \\
\hline None & \multicolumn{2}{|c|}{ Reference category } & \multicolumn{2}{|c|}{ Reference category } & \\
\hline Youngest $<6$ & $-0.630^{\star *}$ & 0.197 & $-0.280^{*}$ & 0.133 & 0.350 \\
\hline Youngest $>=6$ & $-0.521^{\star}$ & 0.245 & -0.350 & 0.208 & 0.171 \\
\hline $\mathrm{N}$ & \multicolumn{2}{|c|}{13,739} & \multicolumn{2}{|c|}{30,792} & \\
\hline $\mathrm{N}$ migrated & \multicolumn{2}{|c|}{219} & \multicolumn{2}{|c|}{327} & \\
\hline-2 Log Likelihood & \multicolumn{2}{|c|}{1,752} & \multicolumn{2}{|c|}{2,910} & \\
\hline Model Chi-Square/DF & \multicolumn{2}{|c|}{$496 / 26$} & \multicolumn{2}{|c|}{$713 / 26$} & \\
\hline
\end{tabular}

Notes: ${ }^{a}$ The dummy variables for cases with missing values on these variables are not presented. ${ }^{\mathrm{b}}$ Significance of the differences between the years is tested with T-tests for independent samples. ${ }^{*} \mathrm{p} \leq 0.05{ }^{\star *} \mathrm{p} \leq 0.01$. 
husband led to significantly more migration; a higher age or working in manufacturing to significantly less.

The educational level of the wife also had a positive effect on migration, at least at the upper secondary and tertiary level. Because of the low labour market attachment of most of these women, this effect of the female's educational level cannot mean that highly educated women used their power to induce a move for their own career. It most likely meant that they could accept a move for their partner more easily, for example because they already had made a long-distance move before to the place where they studied.

In 1977, the presence of children in the household had the expected negative effect on migration only when the children were aged six or over. The fact that the presence of younger children had no effect on migration is not really a surprise, given the fact that in these households the female is at home to take care of the children and hence there is no need to arrange child care after migration. More surprising is that by 1996 the presence of young children does reduce the migration propensity, even in couples with non-employed females. This finding indicates that the non-employed women have also increased their bargaining position within their relationships and nowadays have more possibilities to prevent migration and loss of their local social network than in the past.

The effect of the husband's educational level and most of his labour market characteristics decreased significantly over time. In 1996, the migration propensity was only increased among husbands with tertiary education and the effect of the husband's occupational prestige was no longer significant. Unemployment of the male and working outside the province of residence keep a positive effect of migration, but at a significantly lower level than in 1977. These findings indicate that even in couples where the female was not engaged in paid labour, the importance of the husband's human capital has decreased over time. Hence, the cultural changes in Dutch society in the last decades of the twentieth century seem to have had their impact even in the more traditional households. ${ }^{1}$

The positive effect of the female's educational level on migration is still present in 1996. This might mean that the greater ease with which these highly educated nonemployed women tended to accept a move for their husband's career has remained intact over time.

\section{Couples With Employed Females}

Table 3 describes the models for couples in which the female has a paid job. The interesting question to be answered with this table is whether in 1977 these employed females, who were the most emancipated women at that time in the Netherlands, already showed a more modern pattern of migration behaviour, with a greater importance of resources of the female partner compared to those of the male partner.

A first important difference compared to the findings for couples with nonemployed females is that the effect of the female's educational level is smaller and not significant. This suggests that in 1977 it was at least as important for the highly 
educated women to keep their jobs as it was for less well educated women. It may even mean that preventing migration was more important for the highly educated women. Because many of them had already experienced a long-distance move before (generally to their place of tertiary education), we would have expected them to move more easily than the less well educated women (as we found in the analysis for all women). The fact that no difference with the less well educated women is found, therefore, suggests that the highly educated women made an extra effort to prevent migration.

The effect of the educational level of the husband is strongly positive in 1977 (as it also was for all couples), with an increased migration propensity among husbands with lower and upper secondary or tertiary education compared to husbands with only primary education. Unemployment of the husband also significantly increases the migration propensity. These findings suggest male dominance, even when the female is employed. However, we also find that the effects of the occupational prestige and industrial sector of husbands with employed wives were not significant in 1977, which points to a stronger position for the employed females at that time. The effect of the occupational prestige of employed females is even significantly positive in 1977, but this might be an artefact of the use of occupation after the move for computing occupational prestige. It seems likely that, at that time, the females who were still employed after a long-distance move were those with the strongest motivation to stay employed and thus were probably women in high-level positions.

As could be expected, having a workplace outside the province of either partner increases the migration propensity significantly and an older age of the husband and the presence of children at home decreases this propensity significantly.

If we compare the figures in Table 3 for 1977 with those for 1996, the differences are not very large. The most substantial change has to do with the effect of the male's educational level. That effect is no longer significant in 1996. Another important change is with regard to the effect of unemployment of the husband. Although in 1996, unemployment of the husband still increases the migration propensity, this effect is significantly less strong than in 1977.

The fact that for couples with employed females in 1996 neither the educational level of the husband nor the educational level of the wife had a significant effect on the migration propensity is surprising, given the fact that in the analysis for couples with non-employed females significant positive effects of either partner's education were found for 1996. For the male this difference may mean that he can only profit from a higher educational level if the female is not employed, whereas for the female this might mean an extra effort of the highly educated females to prevent migration (as discussed above for 1977).

In 1996, the effect of a workplace outside the province of either partner is still significantly positive and the effect of a higher age of the husband is significantly negative (and even stronger than in 1977). However, the effect of the presence of children in the household seems to have decreased over time. At least, this is suggested by the fact that in 1996, even when the number of couples in the analysis is higher than in 1977, the presence of young children is only significant at the 0.05 level and the effect of older children is not significant at all. This result is not easy to 
explain. In part, it might be due to the increased availability of child-care facilities in this period.

\section{Age Difference Effects}

The results so far suggest that the influence of the non-employed females increased over time and that the position of the employed females was relatively strong already in 1977. However, the differences and changes in the logistic regression coefficients of the males' and females' human capital and other characteristics constitute rather indirect evidence of the (changes in) the relative positions of the partners and in the way they use their marital power. A more direct way to gain insight into these issues is by adding the age difference variables to the models. The asymmetrical age difference variable directly measures the relative influence of the partners. A high value means that the husband has more influence in this respect, a low (below zero) value that the wife has the upper hand. A significantly positive effect of this variable would point to the classical situation, in which the husband uses his influence to push through a move for his career and the wife would use her influence to prevent migration. A significantly negative effect would mean the reverse, but this situation is highly unlikely.

If the asymmetrical age difference variable has no significant effect, this might mean that there is no age difference effect or that it is too weak to be detected. At least that would be the case in couples with non-employed females. However, if the female partner is employed, absence of the asymmetrical age difference effect could also be expected under the 'new' pattern of migration behaviour in which the female not only uses her power to prevent migration for her partner's career, but also to initiate a move on behalf of her own career if necessary. In the latter case, we would expect an age advantage of either partner to lead to more migration. This possibility is tested with the symmetrical age difference variable.

In our earlier study, the asymmetrical age difference effect was significantly positive both in 1977 and 1996, which suggests dominance of the classical pattern at both time points. However, in 1996 the symmetrical age difference variable was also significantly positive (in a separate model). This indicates that, at least in some cases, the female partner might also be able to initiate a move for her career. If so, these cases most likely will be couples with employed females.

To find out whether this is true, Table 4 presents the coefficients of the age difference variables separately for couples with non-employed and couples with employed females. For the couples with non-employed females, we find the expected classical pattern, with a significantly positive effect of the asymmetrical version and no effect of the symmetrical version. This result indicates that, in these traditional couples, the males indeed used the advantage derived from a higher age to migrate (if necessary), whereas the females used such an advantage to prevent migration. For the couples with employed females in 1977 neither age difference variable is significant. Hence, for these couples there are no indications of a strong classical pattern at that time.

In 1996, the picture is rather different. This time, for the couples with non-employed females, neither age difference variable is significant, which suggests that in these more 
Table 4. Parameter estimates for different specifications of the age difference and the educational difference effects (after controlling for individual, work, and household factors) ${ }^{\mathrm{a}}$

\begin{tabular}{|c|c|c|c|c|c|}
\hline & \multicolumn{2}{|c|}{1977} & \multicolumn{2}{|c|}{ 1995/96 } & \multirow{2}{*}{$\frac{1995 / 96-77}{\text { Difference }^{b}}$} \\
\hline & B & $\mathrm{SE}(\mathrm{B})$ & B & $\mathrm{SE}(\mathrm{B})$ & \\
\hline \multicolumn{6}{|c|}{ Couples with non-employed females } \\
\hline Asymmetrical age difference & $0.035^{\star}$ & 0.015 & 0.027 & 0.015 & -0.008 \\
\hline Symmetrical age difference & 0.027 & 0.017 & 0.028 & 0.018 & 0.001 \\
\hline \multicolumn{6}{|l|}{ Couples with employed females } \\
\hline Asymmetrical age difference & 0.020 & 0.023 & 0.028 & 0.018 & 0.008 \\
\hline Symmetrical age difference & 0.023 & 0.027 & $0.044^{*}$ & 0.022 & 0.021 \\
\hline
\end{tabular}

Notes: ${ }^{\mathrm{a}}$ For each parameter in this table a separate model was estimated. ${ }^{\mathrm{b}}$ Significance of the differences between the years is tested with T-tests for independent samples. ${ }^{*} \mathrm{p} \leq 0.05{ }^{* *} \mathrm{p} \leq 0.01$

traditional couples the strength of the classical pattern has decreased over time. However, for the couples with employed females, the symmetrical age difference variable is significantly positive. This means that, in the mid 1990s, not only an age advantage of the male leads to more migration, but couples in which the female has the higher age also tend to migrate significantly more frequently.

\section{Conclusions}

In this paper, effects of the partner's characteristics on the long-distance migration of couples in the Netherlands in 1977 and 1996 were studied separately for couples with non-employed and couples with employed females. Such a separate analysis is important because the pattern of family migration was expected to differ between the two kinds of couple. For employed women-especially if they are career-oriented-the price to be paid for a move for their husband's career is higher than for non-employed women. Employed women, therefore, can be expected to be more strongly motivated to prevent a move for their husband's career than non-employed women. Furthermore, until as recently as the 1980s, gender roles were very traditional in the Netherlands and the large majority of married women were not gainfully employed. The small number of couples with employed females in 1977 constituted a rather special category, which may have included the most emancipated women (and men) in the Netherlands at that time. It is very possible that the migration behaviour of these 'forerunner' couples differed from that of the more traditional couples. In the earlier analyses of Smits et al. (2003) a distinct migration pattern of this group may have been overshadowed by the pattern of the much larger group of couples with non-employed females.

The results of our analyses reveal that the effects of the partners' characteristics on the couple's migration propensity indeed differed substantially between the two kinds of couple. For the couples with non-employed females, our results for 1977 reveal to a 
large extent the classical pattern of family migration, with relatively strong effects of the husband's human capital and labour market characteristics. The fact that the asymmetrical age difference effect in that year was significantly positive is also in line with this classical pattern. It means that an age advantage of the husband led to more migration whereas an age advantage of the wife led to less. Thus, as predicted by Mincer (1978), in these more traditional couples, the husbands seemed to use the advantage derived from a higher age to push through a move on behalf of their career if necessary, whereas the wives mostly seemed to use such an advantage to prevent such moves for their husbands' careers.

Already in 1977, the employed females had a stronger position within their relationships than the non-employed females. For couples with employed females, the effects of the male's occupational prestige and sector were not significant at that time. The effect of an age difference between the partners was also insignificant, which indicates less male dominance. Over time, the marital power of these females seems to have become even stronger. In 1996, the effect of the husband's educational level is no longer significant and the effect of unemployment of the husband has decreased substantially in strength. Moreover, the effect of the symmetrical age difference variable is significantly positive in 1996, which suggests that at that time at least some of these females were able to use the advantage derived from a higher age to initiate a move for their own career, and hence to turn their husband into a tied mover. Although the number of couples in which the female is older than the male is not very large and hence the extent of this phenomenon of female-induced family migration may be still rather restricted, this result indicates that if women have enough power within their relationship they may be able to break the chains of traditional gender roles and to have their family migrate for the sake of their careers.

Interestingly, our results revealed that the effects of the educational level and most labour market characteristics of the husbands decreased over time for the couples with non-employed women too. The changes for these couples were even stronger than for the couples with employed women. That means that the finding in our earlier paper of a decreasing influence of the male partner's human capital on the migration propensity of the couple was not only caused by a change in the situation of the couples with employed females, but also - and to an even larger extent - by a change in the situation of the couples with non-employed females. This result suggests that the changes that took place in Dutch society between the mid-1970s and the mid-1990s have strengthened the position of women within their relationships regardless of their employment situation.

\section{Note}

[1] Given the large number of cases in the data-sets, one might expect even very small differences without much substantial meaning to become statistically significant and hence that the importance of a coefficient which is statistically significant at the 0.05 level to be not very high. However, in logistic regression analysis it is not the total number of cases, but the number of cases in the smallest category of the dependent variable which counts in this respect. These numbers are not very high: 504 and 219 for 1977 and 345 and 327 for 1996. Therefore, we feel 
confident that the coefficients found in our analyses to be significant at this level point to real and substantial effects.

\section{References}

Bartel, A.P. and Lichtenberg, F.R. (1987) 'The comparative advantage of educated workers in implementing new technologies', Review of Economic Statistics, 69(1): 1-11.

Becker, G.S. (1981) A Treatise on the Family. Cambridge, MA: Harvard University Press.

Bielby, W.T. and Bielby, D.D. (1992) 'I will follow him: family ties, gender-role beliefs, and reluctance to relocate for a better job', American Journal of Sociology, 97(5): 1241-67.

Blau, P.M. and Duncan, O.D. (1967) The American Occupational Structure. New York: Wiley.

Blood, P.M. and Wolfe, D.M. (1960) Husbands and Wives. The Dynamics of Married Living. New York: Free Press.

Bonney, N. (1988) 'Dual-earner couples: trends of change in Great Britain', Work, Employment and Society, 2(1): 89-102.

Bonney, N. and Love, J. (1991) 'Gender and migration: geographical mobility and the wife's sacrifice', The Sociological Review, 39(3): 335-48.

Boyle, P., Cooke, T., Halfacree, K. and Smith, D. (1999) 'Gender inequality in employment status following family migration in GB and the US: the effect of relative occupational status', International Journal of Sociology and Social Policy, 19(9): 109-42.

De Graaf, P. and Vermeulen, H. (1997) 'Female labour market participation in the Netherlands: developments in the relationship between family cycle and employment', in Blossfeld, H.P. and Hakim, C. (eds) Between Equalisation and Marginalisation: Part-Time Working in Europe and the USA. Oxford: Oxford University Press, 191-209.

Green, A.E. (1995) 'The geography of dual career households: a research agenda and selected evidence from secondary data sources for Britain', International Journal of Population Geography, 1(1): $29-50$.

Greenwood, M.J. (1975) 'Research on internal migration in the United States: a survey', Journal of Economic Literature, 13(2): 397-433.

Gregson, N. and Low, M. (1993) 'Renegotiating the domestic division of labour?' Sociological Review, 41(3): 475-504.

Hanson, S. and Pratt, G. (1990) 'A geographic perspective on the occupational segregation of women', National Geographic Research, 6(4): 376-99.

Hooghiemstra, B. and Niphuis-Nell, M. (1993) Sociale Atlas van de Vrouw, Deel 2. Rijswijk: SCP; Den Haag: VUGA.

Lichter, D.T. (1983) 'Socioeconomic returns to migration among married women', Social Forces, 62(2): 487-503.

Long, H.H. (1974) 'Women's labour force participation and the residential mobility of families', Social Forces, 52(2): 342-48.

Markham, W.T. (1987) 'Sex, relocation, and occupational advancement. The "real cruncher" for women', in Stromberg, A.H., Larwood, L. and Gutek, B.A. (eds) Women and Work, Vol II. Beverly Hills, CA: Sage, 207-32.

Markham, W.T. and Pleck, J.H. (1986) 'Sex and willingness to move for occupational advancement: some national sample results', Social Science Quarterly, 27(1): 121-43.

McRae, E.S. and Daniel, W.W. (1991) Maternity Rights: The Experience of Women and Employers. London: Policy Studies Institute.

Mincer, J. (1978) 'Family migration decisions', Journal of Political Economy, 86(5): 749-73.

Mulder, C.H. (1993) Migration Dynamics: A Life Course Approach. Amsterdam: Thesis Publishers.

Polachek, S.W. and Horvath, F.W. (1977) 'A life cycle approach to migration: analysis of the perspicacious peregrinator', in Ehrenberg, R.G. (ed.) Research in Labour Economics, Vol I. Greenwich, CT: JAI Press, 103-49. 
Rodman, H. (1972) 'Marital power and the theory of resources in cultural context', Journal of Comparative Family Studies, 3(1): 50-7.

Shaklee, H. (1989) 'Geographical mobility and the two-earner couple: expected costs of a family move', Journal of Applied Social Psychology, 19(9): 728-43.

Shaw, P.R. (1975) Migration Theory and Fact. Philadephia: Regional Science Research Institute.

Shihadeh, E.S. (1991) 'The prevalence of husband-centered migration: employment consequences for married women', Journal of Marriage and the Family, 53(2): 432-44.

Simpson, W. (1992) Urban Structure and the Labour Market: Worker Mobility, Commuting and Underemployment in Cities. Oxford: Clarendon Press.

Sixma, H. and Ultee, W. (1983) 'Een beroepsprestigeschaal voor Nederland in de jaren tachtig', Mens en Maatschappij, 58(2): 109-31.

Sjaastad, L.A. (1962) 'The costs and returns of human migration', Journal of Political Economy, 70(5, Part 2): 80-93.

Smeenk, W. (1998) Opportunity and Marriage. Amsterdam: Thesis Publishers.

Smits, J. (1999) 'Family migration and the labour-force participation of married women in the Netherlands, 1977-1996', International Journal of Population Geography, 5(2): 133-50.

Smits, J. (2001) 'Career migration, self-selection, and the earnings of married men and women in the Netherlands, 1981-1993', Urban Studies, 38(3): 541-62.

Smits, J., Mulder, C.H. and Hooimeijer, P. (2003) 'Changing gender roles, shifting power balance, and long-distance migration of couples', Urban Studies, 40(3): 603-13.

Spitze, G. (1984) 'The effect of family migration on wives' employment: how long does it last?' Social Forces, 65(1): 21-36.

Topel, R.H. and Ward, M.P. (1992) 'Job mobility and the careers of young men', Quarterly Journal of Economics, 107(2): 439-79.

Van der Lippe, T. (1997) 'Verdeling van onbetaalde arbeid', in Niphuis-Nell, M. (ed.) Sociale Atlas van de Vrouw. Deel 4 Veranderingen in de primaire leefsfeer. Rijswijk: Sociaal en Cultureel Planbureau, 117-57.

Van Ham, M., Mulder, C.H. and Hooimeijer, P. (2001) 'Spatial flexibility in job mobility: macrolevel opportunities and micro-level restrictions’, Environment and Planning A, 33(5): 921-40. 
